\title{
The emerging legal profession in Qatar: diversity realities and challenges
}

\section{Melissa Deehring}

To cite this article: Melissa Deehring (2020): The emerging legal profession in Qatar: diversity realities and challenges, International Journal of the Legal Profession, DOI: 10.1080/09695958.2020.1749059

To link to this article: https://doi.org/10.1080/09695958.2020.1749059

\section{(c) 2020 The Author(s). Published by Informa UK Limited, trading as Taylor \& Francis Group}

曲 Published online: 14 Apr 2020.

Submit your article to this journal

Q View related articles $₫$

View Crossmark data $₫$ 


\title{
The emerging legal profession in Qatar: diversity realities and challenges
}

\author{
Melissa Deehring \\ College of Law, Qatar University, Doha, Qatar
}

\begin{abstract}
In the West, women have practiced law and advocated greater gender diversity in the legal profession for more than a century. In Qatar, concepts such as "equality of opportunity" and "diversity or inclusion in the profession" are virtually unexplored by research and only beginning to appear in casual conversations. While the number of women studying law in Qatar has significantly increased, the number of women practicing law as prosecutors, judges and lawyers has not directly correlated. This article will use Qatar as a case study to analyze how culture and modern development affect the feminization of Qatar's bar and bench.
\end{abstract}

\section{Introduction}

A diverse legal profession is more just, productive and intelligent because diversity, both cognitive and cultural, often leads to better questions, analyses, solutions, and processes. ${ }^{1}$

Diversity in the legal profession is a key initiative of western legal education, bar associations and law societies. In the United States, the American Bar Association (hereinafter "ABA") requires ABA-accredited law schools to promote equal employment opportunities and to demonstrate concrete action of a commitment to diversity and inclusion. ${ }^{2}$ In the U.K., the Law Society of England and Wales advocates its responsibility to encourage access to the profession by promoting diversity in the legal profession. ${ }^{3}$ In France, the "Bâtonnier de Paris" (Head of the Paris Bar Association), signed the "Pacte de l'égalité" to encourage a more diverse legal profession ${ }^{4}$ and reinforced the issue voting on an action plan to ensure equality in the French legal profession. ${ }^{5}$

In Qatar, concepts such as "equality of opportunity" and "diversity or inclusion in the profession" are virtually unexplored by research and only beginning to appear in casual conversations. ${ }^{6}$ While the number of women studying law in Qatar has significantly increased, the number of women practicing law as prosecutors, judges and lawyers has not directly correlated. Enlisting female law graduates to join Qatar's legal profession and diversify it remains a complicated issue due to a mix of social, cultural, and logistical obstacles. 


\section{Qatar: evolution of the state and legal education}

Qatar is a small nation in the form of a peninsula extending northward into the Arabian Sea from the southeastern edge of Saudi Arabia. ${ }^{7}$ The nation's total land area is about 11,500 square kilometers and its total resident population is about 2.7 million people ${ }^{8}$ with an estimated $12 \%$ of the resident population holding Qatari citizenship. ${ }^{9}$ The country is a constitutional monarchy ruled by the AlThani family and has the second largest GDP per capita in the world with oil and natural gas sources contributing the most to revenue. ${ }^{10}$

To understand Qatari legal diversity and meaningfully compare it to Western bars, one must put the Qatari bar's evolution in the context of the country's modern development instead of conducting a side-by-side comparison of current statistics with those of the West. As an example, by 1878, when lawyers in the United States were forming the American Bar Association and Committee on Legal Education \& Admissions to the Bar, ${ }^{11}$ nearly a decade after the first woman was admitted to practice law, ${ }^{12}$ and five years after the first African-American woman was licensed to practice law, ${ }^{13}$ Qatar was occupied by the Ottomans. ${ }^{14}$ By the 1930 's, when women had been admitted as members to the $\mathrm{ABA},{ }^{15}$ and had already formed the National Association of Women Lawyers, ${ }^{16}$ there were more law students registered in US law schools than there were residents of the State of Qatar ${ }^{17}$ and the people of Qatar were starving. ${ }^{18}$

It was only in the 1950's, after the exportation of oil, ${ }^{19}$ that Qatar's first modern primary schools opened with a school for boys opening in 1952 followed shortly by a school for girls in $1955 .{ }^{20}$ Prior to "modern" schools, education existed in the form of the Mutawa (مُطَّوَع (الكتاتيب). Formal non-religious women's primary education initially was not well received, and Qatar's first headmistress, Amnah Mahmood Al Gidah, spent much of her time advocating and convincing parents of its value and necessity. ${ }^{23}$

Most of the girls were prevented from attending school. People were against formal education because they believed it was anti-religious and corruptive. So, I used to explain to them how Islam considered education obligatory for both males and females who should seek it from the moment of birth until death. ${ }^{24}$

In 1961, Qatar's first preparatory level school for girls opened with the full support of the Ministry of Education. ${ }^{25}$ Qatar University (hereinafter "QU”), Qatar's first secondary school, opened simultaneously for men and women in the form of a College of Education in $1973 .{ }^{26}$ Of the original 157 students enrolled in 1973, 103 students were women. ${ }^{27}$

Emiri Decree officially established QU as a public university in 1977 and formal undergraduate legal education began in 1993 with the establishment of the College of Shari'a. ${ }^{28}$ By 2003, QU had six Colleges ${ }^{29}$ and enrolled about 8,600 students of whom $73 \%$ were women. ${ }^{30}$ A College of Law, autonomous 
from the College of Shari'a and Islamic Studies, began operations in 2004 and was formally created in 2006. ${ }^{31}$ By 2015, the College of Law enrolled 1375 undergraduate students, of whom $62 \%$ were female. ${ }^{32}$ By Fall Semester 2017, the College of Law enrolled 557 male undergraduate students, 42 male LLM students, 1,111 female undergraduate students, and 63 female LLM students. ${ }^{33}$

Three new law schools opened in Qatar in recent years. ${ }^{34}$ The Police College opened in 2013 pursuant to Emiri Decree. ${ }^{35}$ The Police College operates under the direction of the Ministry of Interior and offers a four-year Bachelor's degree in law and police science with the aim of training future police officers. ${ }^{36}$ The program is taught in Arabic. In 2015, Hamad Bin Khalifa University began offering a Juris Doctorate degree in law. ${ }^{37}$ The program, taught in English, graduated its first batch of 13 students in 2018 and will graduate its second batch of 12 students in $2019 .^{38}$ Finally, in 2016, the Rule of Law and Anti-Corruption Centre, in collaboration with the University of Sussex, opened a graduate program offering students an L.L.M. in Corruption, Law and Governance. ${ }^{39}$ The program is taught in English and graduated its first batch of 15 students during December of 2018. ${ }^{40}$

\section{Qatar: evolution of the legal profession}

In Qatar, lawyering, as it is known in the West, is a recent profession. While mediation of disputes is an ancient practice with the Prophet Muhammad ${ }^{41}$ himself known for mediating disputes in Medina, ${ }^{42}$ formal court processes with attorneys or legal figures representing aggrieved parties are not.

Traditionally, when disputes would arise between tribes, a "hakam" (الحكم), or mediator, would attempt to mediate ${ }^{44}$ with local Sheikhs and/or the Shari'a courts offering the final resolution of all disputes. ${ }^{45}$ Qatar deviated away from traditional dispute resolution when H.H. Sheikh Abdalla bin Jassim Al-Thani signed the Anglo-Persian Oil Company (hereinafter "APOC") concession on 17 May 1935. By signing the APOC concession, he agreed to allow jurisdiction of any British APOC employees and non-Muslim foreigners to rest solely with the British government and its courts. ${ }^{46}$ This effectively created a dual-court system allowing non-Muslim expatriates to have access to the common law principles of the British courts and Qatari and Muslim expatriates to have access to traditional means and Shari'a courts. In 1971, after Qatar ceased being a British protectorate, ${ }^{47}$ the Adlia court, a civil and commercial court, replaced the British courts for non-Muslim expatriates. ${ }^{48}$ In 2003, a unified judicial court which combined the Shari'a and Adlia courts was created. ${ }^{49}$

\section{Qatar's legal profession: current statistics}

Given the relatively short period during which the formal study and practice of law has been available, Qatar has seen remarkable growth in its legal services 
profession. Qatar currently has more than 160 attorneys licensed to plead before the courts, ${ }^{50}$ a formal Bar Association run by a Board of Directors, ${ }^{51}$ and QU has graduated more than 1,100 law students since $1993 .{ }^{52}$ The Ministry of Justice's Center for Legal and Judicial Studies has trained more than 74 "Judge Assistants,"53 69 "Assistant Prosecutors," 54 "Lawyers" who will be licensed to plead before the Courts, ${ }^{55}$ and 636 "Legal Researchers" ${ }^{56}$ entering different state agencies and institutions. ${ }^{57}$ In 2015, there were a total of 198 judicial officers working within the various courts run by the Supreme Judiciary Council. ${ }^{58}$ In addition to local law firms, two foreign firms are licensed by the Ministry of Justice ${ }^{59}$ and 26 foreign law firms are licensed to operate under the Qatar Financial Centre. ${ }^{60}$

However, despite extremely fast-pace growth in the legal services market, diversity in Qatar's legal profession is still lagging behind. QU College of Law has graduated more than 700 female law students since the University began offering law degrees in $1993 .^{61}$ Yet, despite the number of educated women graduating with law degrees, the State of Qatar only has two female prosecutors, ${ }^{62}$ eight female judicial officers, ${ }^{63}$ women constitute $19 \%$ of licensed attorneys able to plead before the Courts, and Qatari women represent less than $18 \%$ of licensed attorneys. ${ }^{64}$ While women comprise almost $30 \%$ of the law faculty at QU, the number of female faculty in positions higher than "Teaching Assistant" remains almost $13 \%$ of total faculty, versus almost $75 \%$ for the male faculty (Figures 1 and 2). ${ }^{65}$

Qatar is progressing at lightning speed in comparison to the West (the United States only crossed the threshold of $30 \%$ feminization of the bar in $2005,{ }^{66}$ which was 136 years after the first woman was admitted to practice law in one of its states $^{67}$ ) with Qatar hitting 19\% feminization merely 25 years after the

\section{Qatar University College of Law Full-Time Faculty Statistics: Fall Semester 2019}

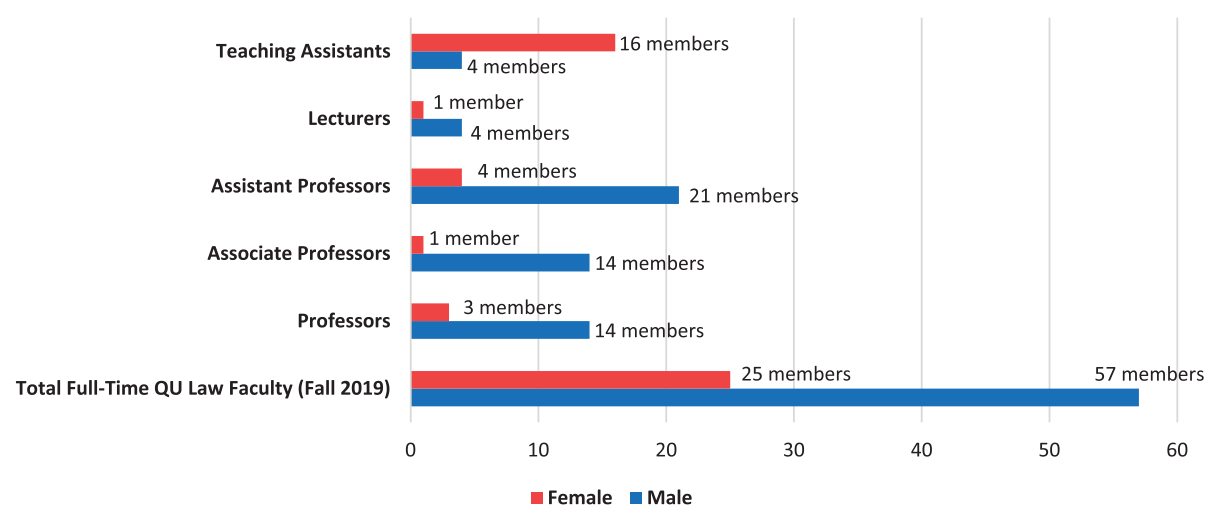

Figure 1. Qatar University College of Law Full-Time Faculty Statistics for the Fall Semester 2019. Notes: Email from QU College of Law to author, supra note 65. 


\begin{tabular}{|c|c|c|c|c|c|c|c|c|c|}
\hline & Gender & St. Disagree & $\begin{array}{l}\text { Somwhat } \\
\text { Disagree }\end{array}$ & Neutral & $\begin{array}{c}\text { Somwhat } \\
\text { Agree }\end{array}$ & St. Agree & Mean & $\begin{array}{l}\text { Total } \\
\text { Mean }\end{array}$ & $S D$ \\
\hline \multirow{2}{*}{$\begin{array}{l}\text { Qatari women should serve in } \\
\text { ministerial positions }\end{array}$} & $\mathrm{M}$ & 30 & 14 & 7 & 26 & 23 & 3 & \multirow{2}{*}{3.38} & \multirow{2}{*}{1.586} \\
\hline & $\mathrm{F}$ & 13 & 10 & 2 & 27 & 47 & 3.9 & & \\
\hline \multirow{2}{*}{$\begin{array}{l}\text { Support Qatari women in Prime } \\
\text { Minister position }\end{array}$} & $\mathrm{M}$ & 56 & 14 & 7 & 12 & 12 & 2.1 & \multirow{2}{*}{2.56} & \multirow{2}{*}{1.644} \\
\hline & $\mathrm{F}$ & 30 & 13 & 3 & 21 & 31 & 3.1 & & \\
\hline \multirow{2}{*}{$\begin{array}{l}\text { Support Qatari women in judge } \\
\text { position }\end{array}$} & $\mathrm{M}$ & 53 & 10 & 5 & 16 & 16 & 2.3 & \multirow{2}{*}{2.3} & \multirow{2}{*}{1.609} \\
\hline & $\mathrm{F}$ & 55 & 11 & 2 & 15 & 17 & 2.3 & & \\
\hline \multirow{2}{*}{$\begin{array}{c}\text { More Qatari women should work as } \\
\text { lawyers }\end{array}$} & $\mathrm{M}$ & 22 & 10 & 6 & 31 & 31 & 3.4 & \multirow{2}{*}{3.74} & \multirow{2}{*}{1.433} \\
\hline & $\mathrm{F}$ & 7 & 5 & 1 & 38 & 49 & 4.2 & & \\
\hline \multirow{2}{*}{$\begin{array}{l}\text { Qatari women should work as } \\
\text { policewomen }\end{array}$} & $\mathrm{M}$ & 19 & 7 & 5 & 38 & 31 & 3.5 & \multirow{2}{*}{3.53} & \multirow{2}{*}{1.514} \\
\hline & $\mathrm{F}$ & 21 & 10 & 2 & 30 & 37 & 3.5 & & \\
\hline \multirow{2}{*}{$\begin{array}{l}\text { Qatari women should be appointed in } \\
\text { diplomatic posts }\end{array}$} & $\mathrm{M}$ & 33 & 12 & 7 & 29 & 20 & 2.9 & \multirow{2}{*}{3.21} & \multirow{2}{*}{1.588} \\
\hline & $\mathrm{F}$ & 18 & 11 & 2 & 31 & 36 & 3.6 & & \\
\hline \multirow{2}{*}{$\begin{array}{l}\text { Qatari women should participate in } \\
\text { political activities just as men do }\end{array}$} & $\mathrm{M}$ & 32 & 15 & 7 & 26 & 21 & 2.9 & \multirow{2}{*}{3.04} & \multirow{2}{*}{1.592} \\
\hline & $\mathrm{F}$ & 25 & 14 & 1 & 33 & 27 & 3.2 & & \\
\hline \multirow{2}{*}{$\begin{array}{c}\text { Qatari women should consult } \\
\text { husbands when they vote in elections }\end{array}$} & $\mathrm{M}$ & 26 & 11 & 4 & 15 & 44 & 3.4 & \multirow{2}{*}{3.46} & \multirow{2}{*}{1.709} \\
\hline & $\mathrm{F}$ & 27 & 7 & 1 & 18 & 47 & 3.5 & & \\
\hline \multirow{2}{*}{$\begin{array}{l}\text { More Qatari women should run for } \\
\text { municipal council elections }\end{array}$} & $\mathrm{M}$ & 29 & 10 & 7 & 29 & 24 & 3.1 & \multirow{2}{*}{3.26} & \multirow{2}{*}{1.592} \\
\hline & $\mathrm{F}$ & 22 & 10 & 2 & 31 & 35 & 3.5 & & \\
\hline \multirow{2}{*}{$\begin{array}{l}\text { Will choose male candidates over } \\
\text { female candidates }\end{array}$} & $\mathrm{M}$ & 15 & 9 & 13 & 17 & 46 & 3.7 & \multirow{2}{*}{3.59} & \multirow{2}{*}{1.494} \\
\hline & $\mathrm{F}$ & 16 & 15 & 11 & 22 & 36 & 3.5 & & \\
\hline
\end{tabular}

Figure 2. Table 6 from Transitional society and participation of women in the public sphere: $A$ survey of Qatar society (emphasis added).

Notes: Al-Ghanim, supra note 98, at 57.

establishment of formal legal education. ${ }^{68}$ However, the argument should be made that legal educational providers and the profession itself need to make greater efforts to embolden women to practice law if they truly seek gender diversification of the local bar. ${ }^{69}$

\section{Qatar's feminization efforts}

Qatar's official policies, legislation and international accords indicate that gender diversity in Qatar's workforce is a priority. Qatar's constitution allows women equal rights and opportunities for education under the law. ${ }^{70}$ The Labour Law provides that women and men shall receive equal pay for equal work and that women "shall be entitled to the same opportunities of training and promotion" as their male colleagues. ${ }^{71}$ The former Human Resources Law, provided that women were entitled to paid maternity leave, ${ }^{72}$ breastfeeding hours, ${ }^{73}$ and Qatari mothers of disabled children were allowed up to three years of fullypaid disability leave. ${ }^{74}$ The new Civil Human Resources Law, provides more generous maternity leave policies and increases the leave for Qatari mothers of disabled children. ${ }^{75}$

Qatari women's right to development is an essential element of the "Social Development Pillar" contained in Qatar's National Vision 2030 (hereinafter "QNV 2030"). ${ }^{76}$ "Social Development" is one of four pillars deemed essential for Qatar's modern development and encompasses the creation of "a system dedicated to social welfare and protection for all citizens and to bolstering women's role in society and empowering them to be active community members." ${ }^{77}$ Concrete actions towards increasing women's empowerment were set out in the Qatar National Development Strategy 2011-2016 
(hereinafter "NDS") ${ }^{78}$ as were methods for improving women's work-life balance. ${ }^{79}$ Qatar acceded to the Convention on the Elimination of All Forms of Discrimination against Women in March 2009 and continues to affirm its commitment to the same. ${ }^{80}$ Finally, H.H. Sheikha Mozah Bint Nasser AlMisnad, mother of H.H. the Emir of Qatar, ${ }^{81}$ as well as her daughters, H.H. Sheikha Hind bint Hamad ${ }^{82}$ and H.H. Sheikha Mayassa bint Hamad, ${ }^{83}$ play major roles inspiring women and promoting their advancement. ${ }^{84}$

Yet, despite the significant efforts taken by Qatar's ruling family and governmental authorities, women's participation in the workforce remains low. ${ }^{85}$ As stated in the NDS,

... traditional views about appropriate avenues for women's employment (educational, administrative or clerical) prevail, despite the new opportunities created by Qatar's economic development ... Although women have higher average educational attainment level than men, there appears to be a "glass ceiling" in employment and promotion for women. ${ }^{86}$

\section{Diversity challenges: culture, restrictive social norms \& kinship systems}

Cultural obstacles and more restrictive social norms arguably create the biggest barrier for feminization of the legal profession in Qatar. ${ }^{87}$ Specific expectations regarding women's societal roles coupled with fears of earning a negative reputation in the community and the lack of role models, tend to discourage women, even those who study law, from pursuing legal careers.

While Qatar has witnessed incredible modernization efforts and increased wealth since the 1960's, one historian noted that this accelerated modernization has not destroyed memories of tribal group power or "the lineage groupings and consequent cultural attitudes and norms of Qataris themselves as quickly as might be expected in classic Western models of development. ${ }^{\text {"8 }}$ He argues that,

... the hold of tribal 'tradition', especially in relation to the marriage practices of women, traditional dress and expected social roles, is often increased, not decreased by wealth and the pursuit of acceptable social status within an extremely wealthy but still extremely lineage-based society. ${ }^{89}$

A 2002 study researching determinants of Qatari nationals entering the job market supports the view that culture and social tradition stand as the biggest obstacle for female graduates entering the practice of law. The study, which interviewed 385 Qatari women during April-June 2001, found that, married Qatari women who have a relatively high level of income (from their husbands, investments or property) and who take care of young children below schooling age have a smaller probability of joining the workforce. ${ }^{90}$ The study found that the availability of domestic help or relatives who could help provide domestic support did not play a significant role in influencing Qatari women's decision 
to enter the workforce. ${ }^{91}$ While the study found that increased education and higher wage rates do increase the probability that Qatari women will work, ${ }^{92}$ the study also found that there is a lower probability that unemployed Qatari women will join the private sector than unemployed Qatari males, ${ }^{93}$ a sentiment still confirmed in Qatar's official labor statistics for 2018. ${ }^{94}$

Qatari kinship systems also play a significant role influencing women's employment decisions ${ }^{95}$ and recent research argues that traditional societal roles constitute substantial obstacles to women entering male-dominated professions. In 2017, Dr Kaltham Al-Ghanim studied responses from more than 1000 Qatari nationals regarding their perceptions of women's rights. ${ }^{96}$ She found that $70 \%$ of respondents believed Qatari women should obtain their husband's permission prior to working and neither age nor educational attainment mattered regarding men's attitudes in this regard. ${ }^{97}$ Additionally, she found that $65 \%$ of respondents agreed with the statement that Qatari married women should work only when they have their husbands' permission and that the majority of respondents strongly agreed with the statement that "Only Certain Jobs Are Suitable For Qatari Women." ${ }^{\text {" }}$ Dr Al-Ghanim also discovered about $50 \%$ of men surveyed did not believe women should work in gender-mixed workplaces while female respondents with more education were more positive about the idea. ${ }^{99}$ Dr Al-Ghanim argued that,

... women's aspirations for work and economic advantages may encourage them to rise above certain restrictive values. Generally, the women respondents were more supportive than the men respondents to women entering new roles even though some new roles were not widely embraced by either, such as work in the media, as lawyers or judges, or military occupations. ${ }^{100}$

Dr Al-Ghanim found that the majority of male and female respondents strongly disagreed when asked whether they would support Qatari women in "judge positions." ${ }^{\prime 01}$ However, more respondents strongly agreed than strongly disagreed with the proposition that more Qatari women should work as lawyers. ${ }^{102}$ Based on the overall number of responses, an argument can be made that attitudes regarding women practicing law as lawyers are changing for the positive. $^{103}$

Yet, while Qatari society might become more accepting of women practicing law, this change does not yet appear to be encouraging more female law students to pursue legal careers. Many Qatari female undergraduate students studying law at QU express that they are not interested in becoming a licensed attorney. Overwhelmingly, the majority of female students who participate in a mandatory Externship Program during their senior $\left(4^{\text {th }}\right)$ year of studies prefer jobs in the government or nonprofit sectors rather than with Qatari or international law firms. ${ }^{104}$ This figure is in line with College of Law alumni statistics that measure only about $6 \%$ of total graduating students choosing to become licensed attorneys. $^{105}$ 


\section{Natural feminization of the Qatari bar}

While research suggests that women naturally enter the practice of law as lawyer density (the number of lawyers per member of the population) increases, looking at Qatar's attorney statistics, it is doubtful that its legal profession will naturally achieve substantial lawyer density any time soon. ${ }^{106}$

A correlation exists between increased gender diversity and a lawyer density of 2,000 people per lawyer; when the majority of countries studied achieved this level of lawyer density, they obtained at least $30 \%$ feminization of the bar. ${ }^{107}$ In Qatar, as all legal residents are entitled, and occasionally required, to access the services of the local courts, official population data suggests the country is not yet close to a lawyer density of 2,000 people per attorney. As of February 2018, Qatar's total resident population stood at little more than 2.7 million people. $^{108}$ During the same time, the Supreme Judiciary Council List of Lawyers contained 152 names. ${ }^{109}$ If we calculate the attorney density by dividing the total number of licensed lawyers by member of the population, Qatar would have a lawyer density of one lawyer per 17,766 people, nowhere near the 2,000 people per attorney bench.

However, while there might be only 152 local attorneys licensed by the State, there are many more attorneys employed by local law firms ${ }^{110}$ and the licensed foreign law firms operating in Qatar. ${ }^{111}$ If we were to estimate that there are nearly 300 foreign licensed attorneys working in Qatar, our statistics regarding lawyer density would be different; Qatar's lawyer density would be one lawyer per 5,974 people, much closer to the critical threshold associated with $30 \%$ feminization of the bar.

Increasing the number of attorneys in Qatar remains a challenge for two key reasons. First, the majority of residents in Qatar are not Qatari citizens, but legal residents holding visas that require regular renewal. ${ }^{112}$ Second, Qatar's "Advocacy Law" and its amendments, which govern the legal profession, specifically state that one of the requirements to the admission of the practice of law in Qatar is Qatari citizenship or G.C.C. citizenship "on the condition of dealing with reciprocity and subject to the approval of the Committee."113 Given the limited number of Qatari citizens and the current political disputes within the G.C.C., it is doubtful that Qatar's legal profession will substantially increase to the levels correlating with increased feminization in the near future. ${ }^{114}$

Further, it is important to note that even if Qatar's legal population did rapidly attain a lawyer density near 2,000 people per attorney, it remains unlikely that $30 \%$ of those attorneys will be women absent significant cultural, social and legal changes. ${ }^{115}$ Dr Cynthia Fuchs Epstein, a prominent sociologist and author of what is widely considered the pioneering research regarding the socio-historical circumstances of women entering the legal profession in the United States, remarked on this more than 30 years ago. 
The future of women in the legal profession cannot be viewed as a simple progression from exclusion to inclusion, with accession to all the rights, privileges, and responsibilities due to any true member of the profession. As in the past, women's future position in the legal world will not depend solely on women's own ambitions, interests, or legal abilities, but on how receptive others may be to these characteristics. It will depend on the disappearance of the stereotypes that define women as unlikely professional partners for men. It will also depend on the decision of the men who guard the gates to the inner core of professional life at all strata of the bar ... ${ }^{116}$

Indeed, this exact sentiment has been expressed in Qatar's Fourth National Human Development Report while noting the minimal community support of female leaders. ${ }^{117}$ Dr Al-Ghanim's aforementioned study also reaffirms that the Qatari population is not automatically receptive to female leadership. ${ }^{118}$ Given the previously mentioned cultural and social barriers, while considering existing structural barriers, ${ }^{119}$ and conservative voices continuing to influence local society, ${ }^{120}$ it is clear that Qatari women's future position in the legal world will very much depend on the disappearance of the stereotypes, not a mere increase in numbers.

\section{Overcoming obstacles: learning from other cultures}

In order to encourage more Qatari women to pursue legal careers, it is important to understand why previous generations of women, albeit from other cultures, chose to pursue legal careers so we may better harness and amplify those motivations in Qatar. As an example, in the United States, women's entrance into the profession was slow until the 1970's. ${ }^{121}$ Despite the fact that women accounted for $1.1 \%$ of all licensed attorneys by 1910 , women constituted merely $4.7 \%$ of all licensed attorneys six decades later in $1970 .{ }^{122}$ As law school enrollments nearly doubled between 1963 and 1978, ${ }^{123}$ and as the number of lawyers increased by $33 \%$ in less than a decade, ${ }^{124}$ the United States witnessed a massive growth in women lawyers in the 1970s and 1980s. ${ }^{125}$

In her seminal book, Dr Fuchs Epstein remarked on several shared characteristics of the women lawyers she interviewed. First, the parents of the women lawyers were more educated than other parents. ${ }^{126}$ Second, a significant percentage, almost a quarter, of the mothers of the women lawyers had a college or professional degree. ${ }^{127}$ Third, researchers found a statistically significant correlation between a mother's education when it was related to the encouragement of her daughter's education. ${ }^{128}$ Fourth, a significant amount of the women lawyers expressed that their mothers possessed "unusual vigor and managerial skill" and described their mothers as "doers," in either a professional or avocational sense. ${ }^{129}$ Fifth, “women who attended college in the 1960's and 1970's were more affected by their peers in deciding on law as a career than preceding generations."

In Qatar, female law students and lawyers today share many of these same characteristics that Dr Fuchs Epstein's subjects did in the 1960's and 1970's. 
First, more young women than ever before in the nation's history have educated parents. Recently reported education statistics show that, as of 2015, the population of Qatari men with university or higher graduate degrees was $29.2 \%$ and the population of Qatari women with university or higher graduate degrees was 37.2\%. ${ }^{131}$ Second, the statistics show that Qatari females constitute the highest proportion of university graduates at $31 \%$ followed by non-Qatari female graduates at $27 \% .^{132}$ Recent datasets collected by the Social and Economic Survey Research Institute (SESRI) and World Values Survey indicate that a significant majority of Qatari respondents, just over 93\% of males and 95\% of females, strongly agreed with the statement that one of their main goals was to make their parents proud. ${ }^{133}$ Other datasets collected by SESRI regarding education in Qatar showed that Qatari men and women who had completed a university degree were more likely to pay for tutors for their children than Qatari men and women without university degrees. ${ }^{134}$

Third, while we might not yet have statistical data in Qatar showing a link between educated parents and parental, particularly motherly, encouragement of their daughters' education with a higher probability of daughters becoming legal professionals, we do have anecdotal evidence. At Qatar's first Women in Law Conference held on 22 March 2018, many of the prominent Qatari legal professionals spoke about or alluded to their families supporting their higher education and career choices, despite those career choices being considered socially deviant in the general community. ${ }^{135}$

\footnotetext{
Women should join the courtroom. In 1985, it was the first year that Qatari ladies were allowed to study abroad. So, I went to Egypt to study law. I graduated from Cairo and joined the Ministry of Justice. Qatar did not have an Office of Public Prosecution at that time. [When the Office of Public Prosecution was created,] I was one of the first ladies who joined. It wasn't easy. A young lady? I was one woman out of 70 people who joined [the office]. It was in 2003, Family Prosecution. Now I am Head of Juvenile and Family Prosecution. ${ }^{136}$
}

Fourth, it is a common viewpoint of Qatari women that their mothers and female relatives are strong capable "doers" and this viewpoint is frequently expressed anecdotally by women in private conversations. H.H. Sheikha Moza Bint Nasser AlMisnad stressed this point while expressing her frustrations about the lack of historical scholarship documenting the societal contributions of women in the Gulf. ${ }^{137}$ "My own experiences and memories of the women who have populated my own life - my childhood memories and the stories passed on to me by my grandmothers - were in complete contradiction to the stereotypes I often encountered regarding Gulf women." ${ }^{\prime 38}$ While formal scholarship depicting the extent to which Qatari women have been and are powerful forces in their communities is relatively recent, ${ }^{139}$ it must remembered that not so long ago, every year, between June and October, the able-bodied Qatari men would leave home to dive for pearls and it would be the Qatari women left with full responsibilities for the family and its affairs. ${ }^{140}$ 
Fifth, with respect to the role and influence of peers, a recent study confirmed Dr Fuchs Epstein's previous findings in a modern context, by arguing that in socially restrictive cultures "where social norms limit women's interactions with strangers, it is important to ask whether training with self-identified friends (with whom interactions are likely less restricted) can have an impact." 141 The scholars concluded that women belonging "to more restrictive social groups were particularly sensitive to peer involvement" and were significantly more likely to change business and financial behavior when they had peer support than women from less socially restricted cultures. ${ }^{142}$ In Qatar, this same phenomenon has been observed at QU College of Law through its Externship Program. After analyzing participation data collected from 394 female law students during the course of 11 academic semesters, this author discovered that female law students self-selected to attend externships with female peers more than $60 \%$ of the time. During all semesters analyzed, only 149 female students, about 38\%, had chosen to be the single female student participating in an externship alone with an employer. The majority of female students chose to participate with at least one female peer. By contrast, male students opted to participate as the only male student during an externship experience $46 \%$ of the time.

While seemingly different at first glance, upon closer inspection, Qatari women entering the law today share common traits with American women who entered the law in the 1960s and 1970s. As Dr Fuchs Epstein has noted, in the 1960s and 1970s many complex factors led to the dramatic growth in women's law school enrollment in the United States including, an increase in demand for legal services due to a growing economy, increasing community concern for individual rights and egalitarianism, rising attorney salaries, more complex and increased government regulation, and a substantial amount of youth interested in pursuing law to accomplish socially oriented goals. ${ }^{143}$ Today, in Qatar, most if not all of these same factors are currently influencing Qatar's legal profession as the State increasingly plays a more significant role in world business and politics. ${ }^{144}$ Similarly, in the 1960s and 1970s, female attorneys entering the job market faced career choices "structured by the interplay between discrimination, adaptation to that discrimination, and opportunity." " Today, in Qatar, as was the same in America in the 1960's and 1970's, many legal employers believe that women's clustering in certain professions, such as government employment, reflects women's preferences, and not necessarily the results of a system of gender stereotyping, explicit and implicit discrimination, and bias. ${ }^{146}$ While some members of the local community openly object to women working in certain legal careers, ${ }^{147}$ due to religious or cultural views, ${ }^{148}$ the more common view is subtler and protective; that women themselves prefer lower-ranking legal specialties and/or jobs that compete less with women's home life and family roles. $^{149}$ 
When I applied to be a judge, there were no forms for applying. So, I gave my papers to the clerk and waited for a year and worked [in another job]. Finally I heard that they were interviewing judges and [I went]. The Chief told me my application never reached him. Sometimes [the Ministry employees] were not referring female applicants. There were more than 50 men who showed up for interviews and I was the only woman. During my interview the first question was, "Can you do the job if you get married? Can you balance your job and family and children?" After the interview, I doubted [I would get an offer] but then I was accepted with three other [women]. ${ }^{150}$

These similarities, despite differences in time and culture, prove certain policies, methods, practices, and pedagogies that previously helped boost diversity in the United States' legal profession, might have a similar effect in Qatar. The similarities also confirm that increased efforts must be taken by the Qatari legal and educational communities to normalize the concept of women working as judges and lawyers ${ }^{151}$ and engage in societal and parental outreach regarding the importance of increased diversity in the legal profession.

\section{Conclusions}

Western scholars predominantly argue that diversity in the legal profession is important because it reflects the profession's core ideals: equality, access to justice and the elimination of bias and discrimination. ${ }^{152}$ The ABA has argued that when the bar reflects a diverse array of lawyers and the bench reflects a diverse array of judges, the public has "greater trust in the mechanisms of government and the rule of law." 153 The ABA has also argued that, as a population ages and becomes more ethnically, racially and culturally diverse, so should the population of professionals in the legal field. ${ }^{154}$ The U.S. Supreme Court remarked that diversity is important because law graduates often possess the skills and social networks preferred for civic leadership positions and frequently represent a significant proportion of a country's leadership. ${ }^{155}$ Industry has shown that in an increasingly multinational and cross-cultural business world, a more diverse team offers different perspectives, life experiences, linguistic skills, knowledge about international markets, legal regimes, different geographies, and current events, which makes those law offices more effective for their clients. ${ }^{156}$

While some of these rationales resonate more readily in Western democracies than in Qatar, ${ }^{157}$ they all remain important considerations for Qatar's continued legal diversity efforts, at least regarding gender. The "Leadership Rationale"158 applies in Qatar, where many law graduates hold prominent positions in governmental ministries and the private sector and also comprise some of the Emir's close advisors. In fact, the Prime Minister ${ }^{159}$ and three out of 14 , or $21 \%$, of the members of Qatar's Council of Ministers hold law degrees ${ }^{160}$ while one Minister holds degrees in Sharia. ${ }^{161}$ The "Business Rationale"162 also applies in Qatar as findings from G.C.C. data collected in 2014 suggest that G.C.C. companies and law firms would do well to add more women to top leadership positions. 
Female leaders in the GCC countries exhibit four leadership behaviors correlated with organizational effectiveness more often than their male counterparts do: inspiration, people development, efficient communication, and participative decision-making. Three of these behaviors are among the leadership styles that [McKinsey's] global survey of top executives found the most effective in addressing the global challenges of the future .... ${ }^{163}$

Even though significant obstacles continue to hinder women's entrance into the Qatari legal profession, it is important to remember just how far the country and its legal profession have come in a relatively short timeframe. Qatar has made significant strides towards diversity in the legal profession during the past 25 years, and enrollment trends and anecdotal evidence suggest this will continue. However, significant diversification in the Qatari legal profession is unlikely to occur as a result of the mere increase in the number of practicing lawyers. Nor will significant diversification happen if Qatari society as a whole fails to understand diversity's importance. When women enter the practice of law, they encourage and support the entrance of other women into the profession. ${ }^{164}$ Eventually, once women are represented in legal institutions and the judiciary, women are able to reshape and adapt laws and their application. ${ }^{165}$ Increasing diversity should not be viewed as the sole responsibility of the women choosing to be socially deviant. ${ }^{166}$ "Society must be prepared to redefine certain aspects of humane concern not as "women's work" but as the work of all." ${ }^{167}$ Alreem $\mathrm{Al}$ Naimi, a young female judicial trainee, recently stated it best, "We Qatari women can succeed in law in Qatar. We should succeed." ${ }^{168}$

\section{Notes}

1. ABA Sec. of Litig. 2011 Corp. Couns. CLE Seminar, Diversity in the Legal Profession: The Next Steps, 5, (Feb. 17-20, 2011), https://apps.americanbar.org/litigation/ committees/corporate/docs/2011-cle-materials/08-Staying-The-Course/08a-diversitylegal-profession\%20.pdf.

2. See ABA Diversity \& Inclusion Portal, https://www.americanbar.org/diversity-portal. html (last visited Nov. 19, 2017); see also ABA Ctr. for Prof. Resp., Diversity Initiatives, https://www.americanbar.org/groups/professional_responsibility/cprdiversityplan. html (last visited Oct. 30, 2017); see also ABA Comm. on Women in the Prof., Goal III Report: An Annual Report on Women's Advancement into Leadership Positions (Apr. 2017), https://www.americanbar.org/content/dam/aba/administrative/women/2016_ goal3_women.authcheckdam.pdf; see also Standards and Rules of Procedure for Approval of L. Schools $\$ 205$ (Am. Bar Ass'n 2017); see also Standards and Rules of Procedure for Approval of L. Schools \$206 (Am. Bar Ass’n 2017).

3. See The Law Society, Diversity Profile of the Solicitors' Profession 2015, 2, (Oct. 2016), https://www.lawsociety.org.uk/support-services/research-trends/promoting-diversityin-the-legal-profession/.

4. See Avocats Barreau Paris, Valeurs et missions, Egalité Professionnelle, https://www. avocatparis.org/nos-engagements/valeurs-et-missions/egalite-professionnelle/le-barreaude-paris-signe-le-pacte-de (last visited Jan. 28, 2018). 
5. Id. at https://www.avocatparis.org/nos-engagements/valeurs-et-missions/egaliteprofessionnelle/le-barreau-de-paris-vote-pour-legalite (last visited Jan. 28, 2018).

6. See The Peninsula Qatar, Role of women in legal field stressed (Mar. 26, 2018), https:// www.thepeninsulaqatar.com/article/26/03/2018/Role-of-women-in-legal-field-stressed,

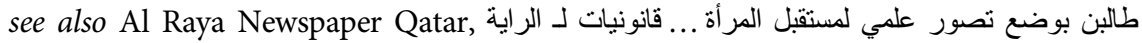
(Mar. 23, 2018) https://www.raya.com/news/pages/7ebd57a6-004c-4890-9559b2ba4b04ffac (Qatar's first Women in Law Conference was held on Mar. 22, 2018. The conference explored: women in leadership; initiatives law firms and departments have taken to increase women in Qatar's legal profession; the realities of gender bias in Qatar; how to use GRIT and Growth Mindset to advance women in the profession; popular literature related to success; women in the courtroom; and how women should approach salary negotiations.)

7. Qatar Tourism Authority, Nat'l Profile: https://www.visitqatar.qa/learn/essentialqatar/national-profile.html (last visited Feb. 24, 2018).

8. Qatar Tourism Authority, supra note 8.

9. See CIA The World Factbook 'Qatar', Population: https://www.cia.gov/library/ publications/the-world-factbook/geos/qa.html (last visited Feb. 24, 2018) [hereinafter CIA].

10. CIA supra note 10 at Introduction and Economy (last visited Feb. 24, 2018).

11. Sandy Ogilvy, A Concise History of Field Placements, Handout from Externships 9: Coming of Age Conf., Plenary I: How Far We Have Come \& How Far We Need To Go, U. of Georgia School of L., Athens, GA (Mar. 9, 2018).

12. See Nat'l Ass'n of Women Law., NAWL History page, https://www.nawl.org/p/cm/ld/ fid $=20$ (last visited Mar. 26, 2018).

13. $I d$.

14. See Zekeriya Kurşun, The Ottomans in Qatar, 15-16 (The Isis Press Istanbul, 2002), see also Allen J. Fromherz, Qatar: A Modern History, 60-61 (I.B. Tauris \& Co Ltd, 2012), see also David B. Roberts, Qatar: Securing the Global Ambitions of a City-State, 17 (London, Hurst \& Company, 2017). (The Ottomans invaded Qatar in 1871 were repelled by the Qataris during the Battle of Wajbah in 1893.)

15. Nat'l Ass'n of Women Law., supra note 13.

16. Id.

17. Ogilvy, supra note 12 (showing that by 1917, in the U.S., there were 146 law schools enrolling 24,503 law students); see also Fromherz, supra note 15, at 1, 74-75; and Roberts supra note 15 at 17-18 (citing Michael Field, The Merchants: The Big Business Families of Saudi Arabia and the Gulf States, 210 (Woodstock, NY: The Overlook Press, 1985) and Rosemarie Said Zahlan, Creation of Qatar, 15 (Croom Helm London, 1979) and Jill Crystal, Oil and Politics in the Gulf: Rulers and merchants in Kuwait and Qatar, 117 (Cambridge Univ. Press 1990). (showing that the collapse of the pearl industry during the 1920's caused significant hardship to the Qatari population. Later deemed the 'years of hunger' it is estimated that the population of Qatar fell from almost 30,000 people in 1908 to around 10,000 inhabitants during the 1930's. By 1940, the population of Qatar was estimated to contain about 16,000 residents but the British Political Resident described Doha as, 'little more than a miserable fishing village straggling along the coast for several miles and more than half in ruins.')

18. See Crystal supra note 18 , at 117.

19. See Crystal supra note 18, at 117-119. (The discovery of oil in 1939 initially did not bring significant changes to Qatar's economy or its population due to World War II. However, once the Petroleum Development Qatar Limited oil company began 
exporting oil in 1949, dramatic increases in revenue created substantial changes to the Qatari economy, population and modern development.).

20. See Abeer Abu Saud, Qatari women, past and present, 173 (Longman 1984). (Note that prior to 1956, there were Koranic schools and the author refers to the first attempt of a modern school which closed in 1938 due to lack of funding.); See also Crystal supra note 18, at 128 (citing Nasir Muhammad al-Uthman's 1980 statement in Arabic that, "the first modern school, Islah al-Muhammadiyya, opened in 1949, offering history, math, geography and some English.")

21. For a more in-depth discussion of the Mutawa and Katateeb see: Ali Alhebsi, Lincoln D. Pettaway and Lee "Rusty" Waller, A History of Education in the United Arab Emirates and Trucial Sheikdoms, The Global ELearning J. Vol. 4, Issue 1, 1-7, (2015) [hereinafter Alhebsi]('Mutawa' pronounced MOO-TA-WAH; 'Katateeb' pronounced EL-QUAY-TEH-TEEB).

22. Alhebsi, supra note 22, at 2. (The Mutawa is another name for the Imam of the Mosque (the religious leader of the community) who traditionally taught children moral obligations as well as how to read the Quran. The Mutawa typically educated students in his home or in the local Mosque. In more affluent communities, students were educated in the Katateeb; a specific physical location resembling modern primary schools where students learned the Holy Quran, Islamic teachings, writing, reading, and basic mathematics.)

23. See Saud supra note 21, at 173.

24. See Saud supra note 21, at 173.

25. Id. at 174 .

26. See Id., see also Qatar U., Our History, https://www.qu.edu.qa/theuniversity/history. php (last visited July 15, 2016), see also Joy S. Moini, et al., The Reform of Qatar University, xviii- xix (RAND Corporation, Santa Monica, CA 2009), https://www.rand. org/pubs/monographs/MG796.html (last visited July 15, 2016) (Initially, the school offered two distinct Colleges of Education, one for men and one for women.)

27. See Saud supra note 21, at 174.

28. See Id.; see also Qatar U. C. of Law, Dean's Message: Welcome to the College of Law, https://www.qu.edu.qa/law/about_us/college/ (last visited July 15, 2016); and Martin Partington, Qatar Int'l Ct. \& Dispute Resolution Ctr, The Development of Professional Legal and Judicial Training in Qatar 17 (2012).

29. See Moini et al., supra note 27, at xiii, xix (The six colleges were: (1) Education; (2) Humanities and Social Sciences; (3) Science; (4) Sharia, Law, and Islamic Studies; (5) Engineering; and (6) Business and Economics).

30. Id. at $9-10$.

31. See Qatar U. C. of Law, https://www.qu.edu.qa/law/about_us/History.php (last visited July 15, 2016).

32. Dr Mohamed Al-Khulaif, Dean of Qatar U. C. of Law, Address at the Annual Law School Dinner (Sept. 3, 2015).

33. Interview with Fatma M. Al-Mesleh, Associate Dean of Student Affairs, Qatar U. C. of Law, in Doha, Qatar (Oct. 6, 2017) (Compiled during Oct. 2017, data showed there were: 382 male freshman students (347 Qatari); 89 male sophomore students (77 Qatari); 43 male junior students (32 Qatari); 43 male senior students (32 Qatari); 18 male private law LLM students (14 Qatari); 31 male public law LLM students (28 Qatari); 507 female freshman students (441 Qatari); 273 female sophomore students (241 Qatari); 180 female junior students (144 Qatari); 151 female senior students (128 Qatari); 35 female private law LLM students (26 Qatari); and 28 female public law LLM students (27 Qatari). 
34. (huge thanks to Maryam Abdulla Al-Mannai, my Honors student, for compiling this information)

35. See Police C. website, https://www.moi.gov.qa/policecollege/ (last visited Mar. 25, 2018) (Emiri decree (161) for 2013.)

36. See Id. at Study Plan page, https://www.moi.gov.qa/policecollege/studying_plan.html (last visited Mar. 25, 2018).

37. See HBKU C. of Law, About the College of Law, https://www.hbku.edu.qa/en/cl/about (last visited Dec. 2, 2019).

38. See Id.

39. See U. of Sussex, https://www.sussex.ac.uk/study/masters/courses/law-politics-andsociology/corruption-law-and-governance-delivered-in-qatar-llm (last visited Mar. 25, 2018); see also Peninsula Newspaper, ROLACC opens online applications for LLM, (Jan. 31, 2018), https://thepeninsulaqatar.com/article/31/01/2018/ROLACCopens-online-applications-for-LLM.

40. See Centre for the Study of Corruption, official blog for the Centre for the Study of Corruption at the University of Sussex, First set of students graduate on University of Sussex's LLM in Corruption, Law and Governance in Doha, Qatar, https:// scscsussex.wordpress.com/2018/12/28/first-set-of-students-graduate-on-universityof-sussexs-llm-in-corruption-law-and-governance-in-doha-qatar/ (Dec. 28, 2018) (last visited Oct. 7, 2019).

41. Peace be Upon Him.

42. See Fromherz, supra note 15 , at 29 .

43. ('hakam' pronounced HA-KM).

44. Fromherz, supra note 15, at 29.

45. See Partington, supra note 29 at 14.

46. See Dr Yousof Ibrahim Al-Abdulla, A Study of Qatari-British Relations 1914-1945, Thesis for (M.A.) MacGill Univ. Montreal, 2nd ed., page 102 (2000) (Appendix IV contains a letter drafted by the Office of the Political Resident in the Persian Gulf on Apr. 17, 1935 to Shaikh Abdullah bin Qasim al Thani, Ruler of Qatar, stating, His Majesty's Government have learnt of the proposal made in the second sub-paragraph of the Eighteenth Article of the Draft Concession which you recently gave to $\mathrm{Mr}$ Mylles in the course of the negotiations which have been taking place between you and him and which reads as follows : 'If any dispute or quarrel should take place between any of the foreign employees of the Company, and any of the Shaikh's subjects, their trial shall be held before the shaikh [sic] and in his Shara (Religious) Courts.' I have been instructed by His Majesty's Government to inform you in regard to this that this condition is one of which they cannot approve, and that an indispensable pre-condition of their approval to the grant by you of any concession, to whomsoever it may be, is a definite understanding that Jurisdiction over the person and property of British and British protected subjects and of the subjects of non-Moslem [sic.] foreign powers will lie solely with His Majesty's Government.)

47. See Fromherz, supra note 15, at 66-73; see also Roberts supra note 15 at 17. (H.H. Sheikh Abdulla bin Jassim Al-Thani signed a formal treaty on Nov. 3, 1916 that, although not specifically saying so, served as the legal foundation for granting Qatar protectorate status with the British government.)

48. See Gabriela Knaul (Special Rapporteur on the independence of judges and lawyers), Rep. of the Special Rapporteur on the independence of judges and lawyers on her mission to Qatar, U.N. Doc. A/HRC/29/26/Add.1, at 4-5 (Mar. 31, 2015) [hereinafter Knaul]; see also Partington, supra note 29, at 14.

49. See Knaul, supra note 59, at 4-5; see also Partington, supra note 29, at 14. 
50. See Supreme Judiciary Council List of Lawyers, https://www.sjc.gov.qa/ar/Pages/ Lawyers.aspx (last visited Oct. 7, 2019) [hereinafter List of Lawyers].

51. See Qatar Lawyer's Ass'n, Board of Directors, https://www.qla.qa/bod/ (last visited Mar. 25, 2018).

52. Interview with Fatma M. Al-Mesleh, Associate Dean of Student Affairs, Qatar U. C. of Law, in Doha, Qatar (Mar. 25, 2018).

53. 'Judge Assistant' is an unofficial translation of: دورات تدريبية لمساعدي القضاة

54. 'Assistant Prosecutor' is an unofficial translation of: دورات تدريبية لمساعدي النيابة العاعة دوريبة

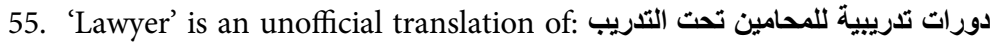

56. 'Legal Researcher' is an unofficial translation of: دورة تدريبية للباحثين القانونيين الجدابن

57. Email from Hazem T. Aboulezz, Legal Researcher, Center for Legal \& Judicial Studies, to Noof M. Al-Sobai, Honors student, Qatar University (Mar. 22, 2018 7:44AST) (on file with author) (huge thanks to Noof M. Al-Sobai, my Honors student, for compiling this information).

58. See Knaul, supra note 59, at 15. (Unfortunately, despite our best efforts, we were unable to procure more recent statistics regarding the total number of judges currently in Qatar).

59. See Partington, supra note 29, at 16 (stating Simmons \& Simmons (UK); Patton Boggs, now Squire Patton Boggs (U.S.); and UGGC (Fr.) are the only foreign law firms licensed to practice law under the Ministry of Justice; note that UGGC stopped operating in Qatar during 2015).

60. See Qatar Fin. Centre, Pub. Register, https://www.qfc.qa/en/Operate/CRO/Pages/ PublicRegister.aspx (last visited Mar. 25, 2018).

61. Interview with Fatma M. Al-Mesleh, Associate Dean of Student Affairs, Qatar U., C. of L., in Doha, Qatar (Oct. 6, 2017).

62. GCC women power through glass ceiling, Arab News (Apr. 16, 2015, 3:00 AM) https:// www.arabnews.com/middle-east/news/733126 (showing that Mariam Abdullah Jaber was appointed the first District Attorney in Qatar in 2003); see also Hiba Fathi,

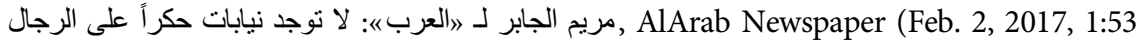

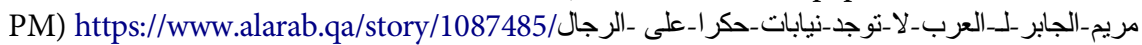
(showing that Maryam's sister, Amal Jaber, became Doha's second female prosecutor).

63. Email from Fatma Al-Mal, Judge, State of Qatar Supreme Judiciary Council, to author (Mar. 11, 2018, 15:22AST) on file with author (The four women who have already trained as Judge Assistants and are now Judges are: Fatma Al-Mal, a criminal judge, and Aisha AlEmadi, Hessa AlSulaiti, and Maha AlThani, who are civil judges); Interview with Reem AlNaimi, Judicial Assistant, State of Qatar Supreme Judiciary Council, in Doha, Qatar (Nov. 22, 2017) (The three women who are training as Judicial Assistants and will eventually seek appointment as Judges are: Reem AlNaimi, Eman AlShahrani and Mariam Al-Hudaifi. Note that during Mar. 2018, the Supreme Judiciary Council announced that Sara M. Al-Mesleh had been chosen to participate as a Judge Assistant and possible future judge pending training.)

64. See List of Lawyers, supra note 61 (which lists 29 registered female attorneys out of a total of 152 registered attorneys (19\%) and 27 registered Qatari female attorneys (17.76\%) (huge thanks to Maryam Yaqoub Al-Jefairi, my Honors student, for compiling this information).

65. Email from QU College of Law to author, entitled "LAWC Directory fall 2019 "دليل أعضاء كلية القانون خريف (Sept. 26, 2019) (on file with author).

66. Ethan Michelson, Women in the Legal Profession, 1970-2010: A Study of the Global Supply of Lawyers, Indiana J. of Global Legal Studies Vol. 20, Issue 2, 1071-1137, 1083 (2013). 
67. See Nat'l Ass'n of Women Law., supra note 13 (to see that in 1869, Arabella Babb Mansfield became the first American woman lawyer admitted to the bar); See also Cynthia Fuchs Epstein, Women in Law 37 (3rd ed. 2012).

68. See Michelson, supra note 66, at 1082. (Figure 1. Feminization of Legal Professions in Eighty-Six Countries, 1960-2010, shows that the U.S. achieved 19\% feminization of the bar around 1985).

69. See Knaul, supra note 59, at 15, (noting that in 2015, only two out of 198 judges were female); See also Qatari Law. Ass'n, supra note 62, (noting that one female attorney, Aisha Saad Nasser, is a member of the Qatari Law. Ass'n Board of Directors).

70. Permanent Constitution of State of Qatar, Arts. 34-35, 49 (Qatar); see also Qatar's Ministry of Development Planning and Statistics, Qatar's Fourth National Human Development Report: Realising Qatar National Vision 2030, The Right to Development, 51, (June 2015) [hereinafter HDR 4] https://www.mdps.gov.qa/en/ knowledge/Doc/HDR/Qatar_Fourth_National_HDR_Realising_QNV2030_The_Right_ to_Development_2015_EN.pdf.

71. Law 14 of 2004, on the promulgation of Labour Law, art. 93 (Qatar) (Jul. 6, 2004) https://www.almeezan.qa/LawArticles.aspx?LawTreeSectionID=12652\&lawId=3961 \&language $=$ en.

72. Law 8 of 2009, on Human Resources Management, art. 108 (Qatar) (Apr. 23, 2009) https://www.almeezan.qa/LawPage.aspx?id=2644\&language $=$ en.

73. Id. at art. 109.

74. Id. at art. 110 .

75. Law No. 15 of 2016, on the promulgation of the Civil Human Resources Law, arts. 73 \& 74 (Qatar) (Nov. 23, 2016) https://www.almeezan.qa/LawPage.aspx?id=7102\&language=ar.

76. See General Secretariat For Development Planning, Qatar National Vision 2030, (July 2008) [hereinafter QNV] https://www.mdps.gov.qa/en/qnv/Documents/QNV2030_ English_v2.pdf; see also HDR 4, supra note 71, at 49-68.

77. Qatar National Vision 2030 Social Development page, Ministry of Development Planning and Statistics, https://www.mdps.gov.qa/en/qnv/Pages/SocialDevelopment.aspx, (last visited Sept. 10, 2018); see also QNV, supra note 86.

78. Qatar General Secretariat for Development Planning, Qatar National Development Strategy 2011-2016, Towards Qatar National Vision 2030, 175-176 (March 2011) [hereinafter NDS], https://www.mdps.gov.qa/en/nds/Documents/Downloads/NDS_ EN_0.pdf.

79. Id. at $174-175$.

80. See U.N. Comm. on the Elimination of Discrimination Against Women (CEDAW), Consideration of reports submitted by States parties under article 18 of the Convention on the Elimination of All Forms of Discrimination against Women : initial reports of States parties / Qatar, at 3, U.N. Doc. CEDAW/C/QAT/1 (21 Mar. 2012) [CEDAW]; see also Qatar 'committed to protecting rights of women', Gulf Times (Oct. 11, 2017, 11:34 PM) https://www.gulf-times.com/story/567060/Qatarcommitted-to-protecting-rights-of-women.

81. H.H. Sheikh Tamim Bin Hamad Al Thani

82. See Sheikha Hind underlines interconnection between education, sustainable development, The Peninsula Qatar (Jul. 9, 2019) https://thepeninsulaqatar.com/article/11/ 07/2019/Sheikha-Hind-underlines-interconnection-between-education,-sustainabledevelopment

83. Qatar has made great strides in gender equality: Mayassa, Gulf Times (Mar. 14, 2019) https://www.gulf-times.com/story/624915/Qatar-has-made-great-strides-in-genderequality-Ma 
84. CEDAW 1, supra note 30, at 8; see also Gender Equality, The Peninsula Qatar (Mar. 20, 2019) https://www.thepeninsulaqatar.com/article/20/03/2019/Gender-equality

85. State of Qatar, Ministry of Development Planning and Statistics, Statistics, Topics Listing, Labour Force, Quarterly Bulletin - Labour Force Survey, First Quarter (Q1) 2018, table 1, Figure 1 (2018) (on file with author) (showing that for Q1 of 2018, there were 66,985 economically active Qatari males and 37,720 economically active Qatari females. 68\% of Qatari men were economically active while only 37\% of Qatari women were economically active).

86. NDS, supra note 88, at 175.

87. See Rania Maktabi, Female lawyers on the rise in Kuwait: Potential agents of reform?, Nat'l U. of Singapore Middle East Institute, Middle East Insights, Insight No. 163, (May 23, 2017), https://mei.nus.edu.sg/themes/site_themes/agile_records/images/ uploads/Download_Insight_163_Maktabi.pdf (for a discussion regarding statistics of female lawyers and female law students in Kuwait); see also Katherine Zoeph, Sisters in Law, The New Yorker, Letter from Jeddah, (Jan. 11, 2016) https://www. newyorker.com/magazine/2016/01/11/sisters-in-law, (for a general discussion regarding female law students in the Kingdom of Saudi Arabia).

88. Fromherz, supra note 15 , at 4 .

89. Fromherz, supra note 15 , at 8 .

90. Professor Mokhtar M. Metwally, Nat'l Center for Economic Research, U. of Qatar, Determinants of National Employment in the State of Qatar, 87 (Jan. 2002).

91. Id. at 88.

92. Id. at 95 .

93. Id.

94. State of Qatar, Ministry of Development Planning and Statistics, Statistics, Topics Listing, Labour Force, Quarterly Bulletin - Labour Force Survey, First Quarter (Q1) 2018, table 12 (2018) (on file with author) (showing that for Q1 of 2018, only 33\% of Qatari women were willing to work in the private sector versus $50 \%$ of Qatari men).

95. Fromherz, supra note 15, at 5-7. (Fromherz makes persuasive arguments about philosophical and sociological perspectives regarding tradition and modernity and that Western perspectives regarding anomie do not apply as well to Qatar).

96. Dr Kaltham Al-Ghanim, Transitional society and participation of women in the public sphere: A survey of Qatar society, Int'l J. of Humanities and Social Science Research, Volume 3, Issue 2, 51-63, (Feb. 2017).

97. Al-Ghanim, supra note 98 , at 56.

98. Id. at 56-57.

99. Id. at 56.

100. Id.

101. Al-Ghanim, supra note 98 , at 57.

102. Id.

103. Id.

104. See Melissa Deehring, Five Years Later: Why More Gulf Law Schools Should Add an Externship Pedagogy, Nat'l U. of Singapore Middle East Institute Insights, Rule of Law Series, MEI Insight No. 160, 3-4, (Feb. 13, 2017), https://mei.nus.edu.sg/ publication/insight-160-five-years-later-why-more-gulf-law-schools-should-add-anexternship-pedagogy/.

105. Interview with Fatma M. Al-Mesleh, Associate Dean of Student Affairs, Qatar U., C. of L., in Doha, Qatar (Mar. 23, 2018).

106. Michelson, supra note 66 , at $1075 ;. .$. lawyer feminization in most parts of the world corresponds closely to the expansion of lawyer populations. In most countries, 
achieving a critical threshold density of lawyers (the number of people per lawyer) is a precondition of achieving a critical threshold proportion of lawyers who are women. Very rarely have countries reached a significant level of lawyer feminization via pathways that do not include significant bar expansion. Id.

107. Id. at $1084-1086$.

108. See Ministry of Development Planning and Statistics website, Monthly figures on total population page, https:/www.mdps.gov.qa/en/statistics1/StatisticsSite/pages/ population.aspx (last visited Mar. 26, 2018) (showing the total population was 2,700,390 with 2,017,612 males and 682,778 females).

109. See List of Lawyers, supra note 61.

110. Quick internet searches of Qatari law firm websites show that, in addition to the Qatari lawyers, there are more than 80 foreign attorneys working in seven large Qatari law firms. See Ghada Darwish Law Firm website, Our Team page, https:/gdarwish.com/ our-team/ (last visited Mar. 26, 2018) (four foreign attorneys); see also Sultan AlAbdulla \& Partners website, Professionals page, https:/qatarlaw.com/professionals/ (last visited Mar. 26, 2018) (18 foreign attorneys); Al Sulaiti Law Firm website, Our Team page, https://alsulaitilawfirm.com/team (last visited Mar. 26, 2018) (23 foreign attorneys); Al-Ansari \& Associates website, People page, https://www.alansarilaw. com/all-people/ (last visited Mar. 26, 2018) (10 foreign attorneys); Law Offices of Gebran Majdalany website, Professionals page, https://www.gebranmajdalany.com/ professionals.html (last visited Mar. 26, 2018) (13 foreign attorneys); Khalid AlAttiya Law Firm website, Firm Lawyers page, https://www.alattiya-legal.com/firm lawyers (last visited Mar. 26, 2018) (nine foreign attorneys); Mashael Al-Sulaiti for Legal Advocacy \& Arbitration website, Our People page, https://sulaitilaw.com/OurPeople.html (last visited Mar. 26, 2018) (four foreign attorneys).

111. Quick internet searches show the two Ministry of Justice licensed foreign law firms employing 22 foreign attorneys. See Simmons \& Simmons website, https://www. simmons-simmons.com/en/People/Contacts?page $=2 \&$ firstname $=\&$ lastname $=$ \&Regions $=$ Middle+East\&mode $=2$ (last visited Mar. 26, 2018) (11 foreign lawyers); see also Squire Patton Boggs website, https://www.squirepattonboggs.com/en/locations/ doha?explore=team (last visited Mar. 26, 2018) (11 foreign lawyers). Quick internet searches show seven of the 26 QFC licensed law firms employing more than 60 foreign lawyers. See Clyde \& Co. website, https://www.clydeco.com/locations/office/ doha (last visited Mar. 26, 2018) (15 foreign lawyers); Al Tamimi Law Firm website, https://www.tamimi.com/our-firm/find-a-lawyer/?searchLocation=1471 (last visited Mar. 26, 2018) (14 foreign lawyers); K\&L Gates website, https://www.clydeco.com/ locations/office/doha (last visited Mar. 26, 2018) (nine foreign lawyers); Dentons website, https://www.dentons.com/en/our-professionals/people-search-results? Locations $=\{$ F77E12C3-5200-44E9-AAB6-1D5C2897FA64 $\}$ (last visited Mar. 26, 2018) (nine foreign lawyers); Eversheds website, https://www.eversheds-sutherland. com/global/en/where/middle-east/qatar/people/index.page? (last visited Mar. 26, 2018) (eight foreign lawyers); Pinsent Masons website, https://www.pinsentmasons. com/en/people/?regions=408 (last visited Mar. 26, 2018) (four foreign lawyers); Allen \& Overy website, https://www.allenovery.com/search/Pages/peopleresults.aspx? $\mathrm{k}={ }^{*} \& \mathrm{r}=$ aooffice\%3d\%22AQREb2hhCGFvb2ZmaWNlAQFeASQ\%3d\%22\&officeid= 738aa486-ad56-11e0-b8b7-68e94724019b (last visited Mar. 26, 2018) (four foreign lawyers).

112. For a description about how Qatar's immigration system affects the independence judicial and legal system see, Knaul, supra note 59, at 11; For demographic estimates regarding the nationality of Qatar's residents see Gulf Labour Markets and Migration 
website, https://gulfmigration.eu/qatar-estimates-foreign-residents-qatar-countrycitizenship-selected-countries-c-2015-2016/ (last visited Mar. 19, 2018).

113. See Law 23 of 2006 regarding Enacting the code of law practice, art. 13 (Qatar) (June 29, 2006) and Law 1 of 2018 regarding Amending the Legal Practice Law promulgated by No. 23 of 2006, art. 13 (Qatar) (Jan. 2, 2018).

114. The G.C.C. nations of Bahrain, Saudi Arabia, and the U.A.E., have initiated a political blockade against Qatar since June 5, 2017, during which time their citizens have been advised to leave Qatar. See AlJazeera, Qatar: Beyond the Blockade (Feb. 15, 2018) https://www.aljazeera.com/programmes/specialseries/2018/02/qatar-blockade-180212 075226584.html.

115. For a detailed description of the complex interplay of factors that contributed to the increase of women in law in the United States see, Fuchs Epstein, supra note 68 at 9-33; Thus growth [of the legal profession], the changing shape of the profession, the move toward egalitarianism and the legal machinery to achieve it, the undermining of the gate-keeping function of the professional elitists, pressure from groups such as black and women's movement activists, and government regulation have created an opening of structure and opportunities in the late 1960s and 1970s. Id. at 16.

116. Id. at 304 .

117. HDR 4 supra note 71 , at $67-68$. While society recognizes the capacities of women as workers, it does not recognize their capacities as leaders, with only $32 \%$ viewing women capable of performing a leadership role...there is an obvious need for public education on the advantages of women's leadership and gender equalities.

118. Al-Ghanim, supra note 98 , at 56. (Showing that the majority of respondents strongly agreed that Qatari women should consult with their husbands before voting in elections and indicated an automatic preference for male political candidates based on no other factor than gender.)

119. As an example, See Law 14 of 2004, on the promulgation of Labour Law, art. 94 (Qatar) (Jul. 6, 2004) (translated into English as "Women shall not be employed in dangerous arduous works, works detrimental to their health, morals or other works to be specified by a Decision of the Minister"), see also Id. at art. 95 ("Women shall not be employed otherwise than in the times to be specified by a Decision of the Minister.").

120. See as example Middle East Media Research Institute, Qatari TV Host Ali Al-Muhannadi: Women Must Leave the House as Little as Possible and Obtain Husband's Permission Whenever They Do, TV Monitor Project, Clip 7316 (Jun. 3, 2019) https://www.memri.org/tv/qatari-host-rashid-muhannadi-woman-wife-leave-househusband-permission-enter-paradise-sin/transcript.

121. Fuchs Epstein, supra note 68, at 2-3.

122. Fuchs Epstein, supra note 68 at 2.

123. Id. at 12 (United States law school enrollments increased from 54,000 to 126,000 between 1963 and 1978.)

124. Id. at 11-12 (Between 1960 and 1969, the number of practicing attorneys in the United States increased by $33 \%$ which was a significant increase from the $14 \%$ growth the profession witnessed a decade earlier).

125. Id. at 3 ("After decades of virtually no movement, the number of women lawyers grew radically in the decade of 1970 to 1980 , from 13,000 to 62,000 (from $4 \%$ to $12.4 \%$ ) and the proportion of women in the law schools rose from $4 \%$ in the 1960 's to $8 \%$ by 1970 , and then to $33 \%$ by $1980 . ")$ For a description of the complex interplay of sociological, political and historical factors triggering women's entrance into the profession see note 119 . 
126. Id at $17-19$.

A 1961 National Opinion Research Center study of college students who chose law as a profession showed that $46 \%$ of the students opting for law had fathers with B.A.'s or higher decrees, as opposed to $21 \%$ of the students choosing careers other than the law. Mothers of pre-law students also had more education than those of their schoolmates: $21 \%$ of the mothers of the pre-law students had B.A.s or higher degrees, compared with $16 \%$ of the mothers of their schoolmates. Id. at 17.

127. Id. at 18 .

128. Id. (citing Rita Lynne Stafford, An Analysis of Consciously Recalled \{Professional Involvement for American Women in New York State (1966) (unpublished PhD thesis, New York University) (on file with the Elmer Holmes Bobst Library, New York University) ("When Stafford asked her sample of eminent women lawyers about fathers' and mothers' encouragement of their professional ambitions, 75\% said that their mothers had encouraged them, and 65\% said their fathers had encouraged them." Id. at 23).

129. Fuchs Epstein, supra note 68, at 20-21 ("The influence of the mother, not as a model but as a "force," may have been more important than any other single factor in guiding some of these daughters into law, although it is difficult to say exactly how their influence was manifested." Id. at 22.)

130. Id. at 25. (2.8\% of the graduating women at Barnard College in 1969 went to law school but merely two years later, in 1971, the percentage had increased to $5.8 \%$. In addition, "An article exploring the changing mood toward law school in 1974 observed that onethird of a recent graduating class at Smith applied, and one-half of the Radcliffe class of 1971 actually went on to law school." Id. (referencing Susan Edmiston, Portia Faces Life: The Trials of Law School, Ms 2, no. 10, 74 (Apr. 1974)).

131. State of Qatar, Ministry of Development Planning and Statistics, Education In Qatar, Statistical Profile 2016, 17 (June 2017) https://www.mdps.gov.qa/en/statistics/ Statistical\%20Releases/Social/Education/2016/Education_Statistical_Pro\%EF\%AC\% 81le_2016_En.pdf, last visited Apr. 1, 2019.

132. Id. at 49.

133. Inglehart, R., C. Haerpfer, A. Moreno, C. Welzel, K. Kizilova, J. Diez-Medrano, M. Lagos, P. Norris, E. Ponarin \& B. Puranen et al. (eds.). 2014. World Values Survey: Round Six Country-Pooled Datafile Version: https://www.worldvaluessurvey.org/WVSDocumentat ionWV6.jsp. Madrid: JD Systems Institute.

134. Qatar Education Study (QES) 2012 Parents Survey [dataset]. Doha, Qatar: Social and Economic Survey Research Institute (SESRI, https://sesri.qu.edu.qa/) [distributor]. May 15, 2018 version (data indicates that about 48\% of Qatari women who self-identified as university graduates indicated their children used private tutors versus about $36 \%$ of Qatari women who self-identified as having completed less education (primary through secondary). Data indicates that about 66\% of Qatari men who self-identified as university graduates indicated their children used private tutors versus about $38 \%$ of Qatari men who self-identified as having completed less education (primary through secondary)).

135. See also Melissa Deehring, Teaching the Women, Peace and Security Agenda in MENA Law Schools, LEXIS MENA Bus. L. Rev. (forthcoming 2020) [hereinafter Deehring LEXIS] (mentioning the oral history project Voices of Qatari Women in International Law and Diplomacy in which almost all of the women profiled and interviewed mentioned their mothers as strong positive personalities and influencers of their daughters' education and career.) 
136. As example Maryam AlJabor, Head of Juvenile and Family Prosecution, State of Qatar Office of Public Prosecution, Remarks at the Women in Law Conference, Qatar University College of Law, Doha, Qatar (Mar. 22, 2018) (translated into English during live translation at the conference).

137. Gulf Women ix-x (Amira El-Azhary Sonbol ed. 2012).

138. Id. at ix.

139. See Deehring LEXIS, supra note 139 (citing as example Melissa Deehring, Voices of Qatari Women in International Law and Diplomacy Oral History Project, Campus \& Student Life in Qatar (@students_qatar) Instagram, https://www.instagram.com/ tv/B47g6mBH5D1/?igshid=mxppcwc6e7va (last visited Nov. 29, 2019); Community Connect Doha (@communityconnectdoha) Instagram, https://www.instagram.com/ p/B468GywATUj/?igshid=t7ucpuqy4x4q (last visited Nov. 29, 2019)).

140. Gulf Women, supra note 141, at 153-155.

141. See generally Erica Field, Seema Jayachandran, Rohini Pande, and Natalia Rigol, Friendship at Work: Can Peer Effects Catalyze Female Entrepreneurship?, Faculty Research Working Paper Series, Harvard Kennedy School of Government, RWP 15019, 4 (Apr. 2015).

142. Id. at $20-21$.

143. Fuchs Epstein, supra note 68, at 11-16.

144. Deehring LEXIS, supra note 139 (mentioning Qatar's growing influence in world trade and international investments, peace negotiations, and military alliances and referencing: Saeed Shah et al., 'Taliban Five,' Once Held at Guantanamo, Join Insurgency's Political Office in Qatar, Wall. St. J. (Oct. 30, 2018) https://www.wsj.com/articles/talibanfive-once-held-at-guantanamo-join-insurgencys-political-office-in-qatar-1540890148; Eric Knecht, Qatar Investment Authority aims to reach \$45 billion in U.S. investments: CEO, Reuters (Jan. 13, 2019) https://www.reuters.com/article/us-qatar-investmentsunited-states/qatar-investment-authority-aims-to-reach-45-billion-in-u-sinvestments-ceo-idUSKCN1P7090; Qatar's investment in Germany to reach $€ 35 \mathrm{bn}$ in next 5 years, The Peninsula (Qatar) (Oct. 18, 2018) https://www.thepeninsulaqatar. com/article/18/10/2018/Qatar\%E2\%80\%99s-investment-in-Germany-to-reach-\%E2\% 82\%AC35bn-in-next-5-years; Mark Brown, Qatar's Sheikha Mayassa tops art power list, The Guardian (London) (Oct. 24, 2013); The Office of Her Highness Sheikha Moza bint Nasser, UN Secretary-General re-appoints HH Sheikha Moza as UN Sustainable Development Goals' Advocate, Doha (May 9, 2019) https://www.mozabintnasser. qa/en/news/un-secretary-general-re-appoints-hh-sheikha-moza-un-sustainabledevelopment-goals\%E2\%80\%99-advocate\%C2\%A0; Qatar Ministry of Foreign Affairs website, Foreign Policy, Preventative Diplomacy page https:/www.mofa.gov.qa/en/ foreign-policy/preventive-diplomacy (last visited Jul. 28, 2019); \#IPU140 Assembly in Doha to focus on education, gender equality and counter-terrorism, Inter-Parliamentary Union Press Release (Apr. 1, 2019) https://www.ipu.org/news/press-releases/ 2019-04/ipu140-assembly-in-doha-focus-education-gender-equality-and-counterterrorism; Shereena Qazi, Intra-Afghan talks with Taliban under way in Qatar, AlJazeera (Doha) (Jul. 7, 2019) https://www.aljazeera.com/news/2019/07/qatar-hostsintra-afghan-summit-peace-talks-taliban-190706134720995.html; Brad Lendon, Qatar hosts largest US military base in Mideast, CNN (Jun. 6, 2017) https://edition. cnn.com/2017/06/05/middleeast/qatar-us-largest-base-in-mideast/index.html.)

145. Fuchs Epstein, supra note 68, at 77; see also Id. at 63-76 and 209-237.

146. Id. at $78-87$.

147. Such as being a judge, particularly a criminal judge, and/or a public prosecutor. 
148. Surah An-Nisa 4:34-42 which refers to men being the protectors of women and women's obedience is the most commonly cited reference for this thinking. https:// quran.com/4/34?translations=18,21,22,84,95 (Thank you to my former law student, Maryam Ahmed Al-Maraghi, for helping me research this issue.)

149. Fuchs Epstein, supra note 68, at 86-89.

150. Alreem Al Naimi, Judge Assistant, State of Qatar Supreme Judicial Council, Remarks at the Women in Law Conference, Qatar University College of Law, Doha, Qatar (Mar. 22, 2018).

151. Melissa Deehring, The Push for Practical Skills Education in Qatar: Results from an Externship Program, Int'l Rev. of L., Vol. 2016, Issue 2 (2016) https://www.qscience. com/doi/pdf/10.5339/irl.2016.10.

152. See Eli Wald, A Primer on Diversity, Discrimination, and Equality in the Legal Profession or Who is Responsible For Pursuing Diversity and Why, 24 Geo. J. Legal Ethics 1079, 1079-81 (2011); see also Paul M. George and Susan McGlamery, Women and Legal Scholarship: A Bibliography, Faculty Scholarship Paper 1248, (1991) https://scholarship.law.upenn.edu/faculty_scholarship/1248 (last visited Mar. 25, 2018); Sandra Petersson, New Zealand Bibliography of Women and the Law 1970-2000, 32 Victoria U. Wellington L. Rev. [ix] (2001); Jason P. Nance \& Paul E. Madsen, An Empirical Analysis of Diversity in the Legal Profession, Conn. L. Rev. Vol 47, No. 2, 217, 279-281 (Dec. 2014) (section II. Literature Review and Theory provides a well-written overview of pro-diversity arguments); see generally ABA Women in the Prof. Resources, Articles, Reports, Research, \& Organizations / Initiatives By Topic, https://www.americanbar.org/groups/women/resources/articles_reports_ research_topic.html\#diversity) (last visited Mar. 25, 2018); Nat'l Ass'n of Women Lawyers, https://www.nawl.org/ (last visited Mar. 20, 2018); Mary Jane Mossman, The First Women Lawyers: A Comparative Study of Gender, Law and the Legal Professions 54 (2006); Jean McKenzie Leiper, Bar Codes: Women in the Legal Profession (2006).

153. ABA Sec. of Litig. supra note 2, at 5 (This argument is referred to as the 'Democracy Rationale').

154. ABA Sec. of Litig. supra note 2, at 5. (This argument is referred to as the 'Demographic Rationale').

155. Grutter v. Bollinger, 539 U.S. 306, 332-3 (2003) ("Individuals with law degrees occupy roughly half the state governorships, more than half the seats in the U.S. Senate, and more than a third of the seats in the U.S. House of Representatives."), see also Deborah L. Rhode, Lawyers as Leaders, 1 (2013) ("Although they account for just $0.4 \%$ of the population, lawyers are well-represented at all levels of [American] leadership, as governors, state legislators, judges, prosecutors, general counsel, law firm managing partners, and heads of corporate, government, and non-profit organization."); see also ABA Sec. of Litig. supra note 2, at 5 (This argument is referred to as the 'Leadership Rationale').

156. ABA Sec. of Litig. supra note 2, at 9 (This is referred to as the 'Business Rationale').

157. (The 'Democracy' or 'Demography' rationales might work better in cultures where work-related social identity is the prevailing culture instead of tribal lineages or in countries where citizens compose the majority of legal residents.)

158. Supra note 141.

159. See Government Communications Office, State of Qatar website, Prime Minister And Minister Of Interior page, available at https://www.gco.gov.qa/en/about-qatar/theprime-minister/ (showing H.E. Sheikh Abdullah bin Nasser bin Khalifa Al Thani, 
Prime Minister And Minister Of Interior holds a law degree from Beirut Arab U.) (last visited Mar. 19, 2018).

160. See Government Communications Office, State of Qatar, Council Of Ministers, https:// www.gco.gov.qa/en/ministries/minister-of-justice/ (last visited Mar. 19, 2018) (H.E. Dr Khalid bin Mohamed Al Attiyah, Deputy Prime Minister And Minister Of State For Defence Affairs; H.E. Dr Hassan Bin Lahdan Saqr Al Mohannadi, Minister Of Justice; H.E. Dr Issa Saad Al Jafali Al Nuaimi, Minister Of Administrative Development, Labour And Social Affairs hold law degrees).

161. See Id. (H.E. Dr Gaith bin Mubarak Al Kuwari, Minister Of Endowments (Awqaf) And Islamic Affairs holds degrees in Sharia).

162. Supra note 142 .

163. McKinsey \& Company, Women Matter: Time to accelerate: Ten years of insights on gender diversity, 16 (Oct. 2017); see also Credit Suisse Research Inst., The CS Gender 3000: The Reward for Change, 25-27 (Sept. 2016) (Researchers found that by increasing the number of women in top management positions within an organization, companies directly increased their share price. Companies who had at least $33 \%$ women in top management paid a dividend $6.8 \%$ higher and companies who had more than $50 \%$ women in top management, paid an annual dividend $14.8 \%$ higher than average.)

164. Fuchs Epstein, supra note 68 at 306.

165. Id.

166. Id. at 307.

167. Id.

168. Alreem Al Naimi, supra note 150.

\section{Acknowledgements}

This paper was made possible by NPRP grant \#9-341-5-047 from the Qatar National Research Fund (a member of Qatar Foundation). The statements made herein are solely the responsibility of the author. Thank you to Arnaud Montouché, Emily Tomczak, Sara A. AlMohanadi, Maryam A. Al-Maraghi, Amna A. Al-Ansari, the AALS Externship Scholarship Committee's inaugural Works-in-Progress participants, Paula M. Young of Qatar University, Carole Heyward of Cleveland State, and the anonymous peer reviewers for their constructive feedback and insight during the revision process.

\section{Disclosure statement}

No potential conflict of interest was reported by the author(s).

\section{Funding}

This paper was made possible by the Qatar National Research Fund [grant number NPRP 9341-5-047] (a member of Qatar Foundation). The publication of this article was funded by the Qatar National Library. 